\title{
ВИДОВОЙ СОСТАВ И ЭКОЛОГО-ТРОФИЧЕСКИЕ ОСОБЕННОСТИ РОДА COLLETOTRICHUM CORDA В УСЛОВИЯХ ЗАКРЫТОГО ГРУНТА ЦБС НАН АЗЕРБАЙДЖАНА
}

\section{SPECIES COMPOSITION \\ AND ECO-TROPHIC FEATURES \\ OF THE GENUS COLLETOTRICHUM \\ CORDA IN THE GREENHOUSE \\ OF THE CBG. OF THE NAS OF AZERBAIJAN \\ S. Veliyeva}

Summary. In the article are presented species composition of pathogenic micromycetes from the genus Colletotrichum Corda on the tropical plantsintroducents to the greenhouse of the Central Botanical Garden of the National Academy of Sciences of Azerbaijan. In the course of researche were identified 8 pathogenic anamorphic species (Colletotrichum crassipes (Speg.) Arx, C. gloeosporioides (Penz.) Penz.\&Sacc., C.destructivum 0'Gara, C. cliviae Yan L. Yang, C. musae (Berk.\&M.A. Curtis) Arx, C. orchidearum Allesch., C. roseolum Henn., C. orthianum Kostlan) from the genus Colletotrichum, belonging to the Ascomycota division, the Sordariomycetes class, the Hypocreomycetidae subclass, the Glomerellales order, and the Glomerellaceae family. It was found 25 taxa of identified species of phytopathogens, which growth and development on the research plants. It was noted that the detected pathogenic micromycetes from the genus Colletotrichum represent the causative agents of the anthracnose disease on the vegetative and generative organs of tropical plants in the greenhouses. Described the morphology and biology features of micromycetes.

Keywords: Colletotrichum Corda, pathogenic micromycetes, anthracnose, eco-trophism, closed ground, tropical plants.

\section{Введение}

B настоящее время существует огромное количество научных трудов и материалов, посвященных грибным болезням сельско-хозяйственных и цветочно-декоративных растений, выращиваемых в про мышленных масштабах [17, 20], в то время как проблеме грибных болезней субтропических и тропических растений в условиях закрытого грунта не уделяется должного внимания[13]. Особенно это проблема актуальна для ботанических садов, где содержится большое количество видов и сортов растений [10], многие из которых сильно страдают от разных фитопатогенных микроорганизмов, в частности, микромицетов [11-12, 18]. Так, биотрофные виды микромицетов отрицательно влияют на процес-

\author{
Велиева Сафура Сахиб кызы \\ Диссертант(PhD), Институт Микробиологии НАНА, \\ Азербайджан, Баку \\ gshakir@mail.ru
}

Аннотация. В данной статье приведен видовой состав патогенных микромицетов рода Colletotrichum Corda тропических растений-интродуцентов закрытого грунта ЦБС НАН Азербайджана. В ходе проведенного исследования выявлено 8 патогенных анаморфных видов (Colletotrichum crassipes (Speg.) Arx, C. gloeosporioides (Penz.) Penz.\&Sacc., C.destructivum 0'Gara, C. cliviae Yan L. Yang, C. musae (Berk.\&M.A. Curtis) Arx, C. orchidearum Allesch., C. roseolum Henn., C. orthianum Kostlan) рода Colletotrichum, относящихся к отделу Ascomycota, классу Sordariomycetes, подклассу Hypocreomycetidae, порядку Glomerellales и семейству Glomerellaceae. Установлено 25 таксонов питающих растений, на которых проходит рост и развитие выявленных фитопатогенных видов. Установлено, что обнаруженные патогенные микромицеты рода Colletotrichum являются возбудителями болезни — антракноза на вегетативных и генеративных органах тропических растений в закрытом грунте. Описаны морфология и особенности биологии микромицетов.

Ключевые слова: Colletotrichum Corda, патогенные микромицеты, антракн0з, эко-трофика, закрытый грунт, тропические растения.

сы жизнедеятельности растений, ослабляют их способность к перезимовке, долговечность, семенную продуктивность, снижают декоративные качества растений, а сапротрофные виды, поселяясь на ослабленных или травмированных растениях, приводят к разрушению их тканей, что ускоряет их гибель [1, 21]. Поэтому изучение видового состава патогенной микобиоты растений диктуется непосредственными научными и практическими задачами интродукции и акклиматизации.

Надо отметить, что видовой состав возбудителей заболеваний того или иного растения в разных климатических зонах имеет свою специфику $[4-5,7]$. Поэтому первостепенное значение для решения практических вопросов по защите растений, в том числе интродуцен- 
тов, имеют исследования по инвентаризации паразитных грибов в конкретных местных условиях. Только уточнение видового состава фитопатогенных грибов и особенностей их развития позволяют научно обосновать необходимость защитных мероприятий.

Как отмечалось выше, грибные болезни субтропических и тропических растений в настоящее время в мире изучены недостаточно. В условиях Азербайджанской Республики данный вопрос вообще не исследован, даже несмотря на то, что в коллекции ЦБС НАН Азербайджана насчитывается 294 видов субтропических и тропических растений [2].

В этой связи, целью представленной работы явилось изучение грибных болезней тропических растений в закрытом грунте Азербайджана. Учитывая многочисленность грибных болезней и их возбудителей, в ходе работы исследовались патогенные виды грибов рода Colletotrichum Corda, которые вызывают антракноз различных растений [14-15, 18-19].

\section{Объекты и методы исслеАований}

Объектами исследования являются возбудители болезни антракноза тропических растений в закрытом грунте в сухих субтропических зонах Азербайджана. Изученные возбудители антракноза являются представителями анаморфных видов рода Colletotrichum Corda.

Идентификация и описание микромицетов, относящихся к роду Colletotrichum, осуществлялись на основе методов и подходов, использованных в работе различных авторов [9, 16]. Названия грибов, их синонимы и систематическое положение приведены в соответствии с базой данных Интернет-ресурса CABI Bioscience Database [8].

Названия тропических растений приведены по Б.Н. Головкину, В.Н. Чекановой, Г.И. Шаховой и др. [3], а также по Т.М. Черевченко, С.Н. Приходько, Т. К. Майко и др. [6].

Идентификацию микромицетов проводили в Институте Микробиологии НАН Азербайджана. В работе использовали бинокулярные микроскопы МБС-9 и "OMAX 40X-2500X LED Digital Lab Trinocular Compound Microscope".

\section{Обсужьение и результаты}

В результате анализа микологического состава коллекции тропических растений, выращиваемых в закрытом грунте Центрального ботанического сада НАН Азербайджана, выявлено 8 патогенных видов
(Colletotrichum crassipes (Speg.) Arx, C. gloeosporioides (Penz.) Penz.\&Sacc., C.destructivum O'Gara, C. cliviae Yan L. Yang, C. musae (Berk.\&M.A. Curtis) Arx, C. orchidearum Allesch., C. roseolum Henn., C. orthianum Kostlan) рода Colletotrichum.

Систематическое положение микромицетов рода Colletotrichum: Fungi, Ascomycota, Pezizomycotina, Sordariomycetes, Hypocreomycetidae, Glomerellales, Glomerellaceae, Colletotrichum.

В результате проведенного миколого-трофического анализа коллекции тропических растений закрытого грунта было установлено 25 таксонов питающих растений, на которых происходит рост и развития выявленных видов патогенных микромицетов рода Colletotrichum.

Ниже приводится список видов патогенных микромицетов, развивающихся на надземных органах (вегетативных и генеративных) тропических растений закрытого грунта (Таблица 1).

\section{Colletotrichum crassipes (Speg.) Arx,} PhytopathologischeZeitschrift 29 (4): 448 (1957)

=GloeosporiumcrassipesSpeg., Rivista di Viticoltura e di Enoligia di Conegliano 2:405 (1878)

Морфология. Анаморфный микромицет Colletotrichum crassipes представлен конидиями на коротких конидиеносцах в специальных конидиальных ацервулах. Они выступают на поверхность субстрата в виде плоских подушечек. Конидиеносцы этого патогенного микромицета короткие, расположены скученно, по краям конидиального ложа находятся темные щетинки. Конидии одноклеточные, бесцветные, серповидной, цилиндрической формы размером 10,4-19,5×3,6-6,7 МКM.

Биологические особенности микромицета. Микромицет вызывает пятнистость органов тропических растений. На зараженных органах происходит спороношение. Первые признаки болезни появляются в первой декаде мая и до второй декады июня. При этом, на надземных органах растений формируются сплошной налет в виде темно-коричневых пятен с концентрическими кругами. В течение вегетационного периода патоген закрытого грунта распространяется конидиями во время полива и при сквозном проветривании. Микромицеты C. Crassipes могут развиваться при температуре от +4,5-50С до 29-310С. Оптимальная влажность составляет 88-98\%. При относительной влажности около 5565\% активность микромицета снижается.

Питающие растения. Phoenix dactylifera L., Chamaerops humilis L., Vallota speciosa Dur., Ananas 
Таблица 1. , Микромицеты, развивающиеся на надземных органах тропических растений закрытого грунта ЦБС НАН Азербайджана

\begin{tabular}{|c|c|c|c|}
\hline № & Виды патогенных микромицетов & Питаюшие растения & Семейства растений \\
\hline 1 & 2 & 3 & 4 \\
\hline \multirow{4}{*}{1.} & \multirow{4}{*}{ Colletotrichum crassipes } & Phoenix dactylifera, Chamaerops humilis; & Arecaceae \\
\hline & & Vallota speciosa; & Amaryllidaceae \\
\hline & & Ananas comosusvariegatus; & Bromeliaceae \\
\hline & & $\begin{array}{l}\text { Parodia magnifica, Rebutia krainziana, } \\
\text { R. minuschula }\end{array}$ & Cactaceae \\
\hline \multirow{4}{*}{2.} & \multirow{4}{*}{ C.gloeosporioides } & Persea americana; & Lauraceae \\
\hline & & Citrus limon, Fortunella margarita; & Rutaceae \\
\hline & & $\begin{array}{l}\text { Opuntialindheimeri, Op. linguiformis, } \\
\text { Op. macracantha, Mammillariaprolifera; }\end{array}$ & Cactaceae \\
\hline & & Anthurium andreanum, Zantedeschia aethiopica & Araceae \\
\hline 3. & C.destructivum & Anthurium scandens & Araceae \\
\hline 4. & C. cliviae & Clivia miniata & Amaryllidaceae \\
\hline \multirow{2}{*}{5.} & \multirow{2}{*}{ C. musae } & Musa basjoo; & Musaceae \\
\hline & & Aspidistraelatior & Liliaceae \\
\hline 6. & C. orchiderum & $\begin{array}{l}\text { Cattleya hybrida, Cymbidium hybridum, Coelogyne cristata, } \\
\text { Dendrobium nobile, Stanhopea tigrina }\end{array}$ & Orchidaceae \\
\hline 7. & C. roseolum & $\begin{array}{l}\text { Cattleya hybrida, Cymbidium hybridum, Coelogyne cristata, } \\
\text { Dendrobium nobile, Stanhopea tigrina }\end{array}$ & Orchidaceae \\
\hline 8. & C. orthianum & $\begin{array}{l}\text { Cattleya hybrida, Cymbidium hybridum, Coelogyne cristata, } \\
\text { Dendrobium nobile, Stanhopea tigrina }\end{array}$ & Orchidaceae \\
\hline
\end{tabular}

comosus (L.) Merr. variegatus hort, Parodia magnifica (F. Ritter) F.H. Brand, Rebutia krainziana Kesseir, $R$. minuschula $\mathrm{K}$. Schum.

Общее распространение. Широко распространен по миру.

C. gloeosporioides (Penz.) Penz.\&Sacc., Atti dell'Istituto Veneto Scienze 2:670 (1884)

= Vermiculariagloeosporioides Penz., Michelia 2 (8): $450(1882)$

Морфология. Конидии образуются во время влажной погоды и заражают здоровые ткани растений через брызги воды. Ацервулы представляют собой гимениальный слой, состоящий из тесно сидящих конидиеносцев. Конидиеносцы удлиненные, бесцветные, палочкообразные, расположены тесным плотным слоем и большей частью субэпидермально, на поверхности пораженной ткани выступают только конидии. Конидии возникают акрогенно друг за другом и легко отделяются от конидиеносцев. Конидии одноклеточные, бесцветные, удлиненные, реже эллипсоидальные с закругленными концами, 6,7-10,9х2,7-3,0 мкм.

Биологические особенности микромицета. C. Gloeosporioides является одним из широко распро- страненных и вредоносных возбудителей антракнозов на тропических растениях закрытого грунта Азербайджана. Этот микромицет вызывает гниение вегетативных и генеративных органов тропических растений. Первые признаки болезни появляются в мае и до первой декады июня. При этом, на органах растений формируются пятна - от небольших красноватых коричневых круглых пятен до больших черных пятен неправильной формы с концентрическими гнойными кольцами. Болезнь может возникать в течение всего вегетатционного сезона, если создаются благоприятные условия для ее развития. C. gloeosporioides является гемибиотрофом, то есть он занимает промежуточное положение между биотрофами и сапрофитами.

Питающие растения. Persea americana Mill., Citrus limon (L.) Burm., Fortunella margarita Swingle, Opuntia lindheimeri Engelm., Op. linguiformis Griffiths, $O p$. macracantha Griseb., Mammillaria prolifera (Mill.) Haw., Anthurium andreanum Lind., Zantedeschia aethiopica Spreng.

Общее распространение. Азербайджан, Грузия и субтропические зоны.

C.destructivum O'Gara, Mycologia 7 (1): 38 (1915) 
Морфология. Конидии яйцевидные, светлые, одноклеточные, продолговатые, размером 3,1-5,2×2,4-3,6 мкм. Короткие конидиеносцы образуются в сероватых подушечках-ложах без щетинок.

Биологические особенности микромицета. Микромицет зимует в форме мицелий в пораженных органах. Весной образуется конидиальное спороношение и телеоморфа. Первые признаки болезни появляются в первой декаде мая и до первой декады июня. В местах поражения образуется мицелий. На эпидермисе пораженной ткани растений образуется ацервула конидиеносцев с конидиями. Конидии прорастают при температуре от +100С до +39-400С и высокой влажности.

Питающие растения. Anthurium scandens Engl.

Общее распространение. Субтропические и тропические зоны.

C. cliviae Yan L. Yang, Zuo Y. Liu, K.D. Hyde\&L. Cai, Fungal Diversity 39: 133 (2009)

$=$ Colletotrichum cliviicola Damm\&Crous, Studies in Mycology 92: 11 (2018)

Морфология.Конидии бесцветные, продолговатые, одноклеточные. Характерный признак ацервулы микромицета - бурые щетинки с утолщениями к основанию и заостренными верхними концами.

Биологические особенности микромицета. Инфекция на листьях $C$. cliviae вначале проявляется в виде незначительных обесцвеченных, быстро увеличивающихся в размерах, затем сливающихся пятен. Поражение обычно начинается с края листа, затем распространяется до центральной жилки. При благоприятных условиях болезнь может распространиться на все листья и вызывать их увядание.

Процесс образования конидиального спороношения длится в течение всего времени, пока инфекция не распространится по всему листу. Ацервулы представляет собой гимениальный слой, состоящий из тесно сидящих конидиеносцев, расположенных на более или менее плотном сплетении грибных гиф.

\section{Питающие растения. Cliviaminiata $\mathrm{Rgl}$.}

Общее распространение. Субтропические и тропические зоны.

C. musae (Berk.\&M.A. Curtis) Arx, Phytopathologische Zeitschrift 29 (4): 446 (1957)

$=$ MyxosporiummusaeBerk.\&M.A. Curtis, Grevi; llea 3 (25): 13 (1874); = Gloeosporium musarum Cooke\&Massee, Grevillea 16 (77): 3 (1887)
Морфология. Конидии мелкие, одноклеточные и изогнутые. Конидиеносцы короткие, бесцветные. В ложах микромицета отсутствуют щетинки.

Биологические особенности микромицета. C. musae зимуют обычно в форме мицелия в пораженных побегах. Весной на мицелии образуется конидиальное спороношение и телеоморфа. В течение вегетационного периода конидии патогена закрытого грунта распространяются во время полива и при сквозном проветривании. В местах пораженных органов образуется мицелии. Конидии прорастают при температуре от +110С до +390С и высокой влажности.

Питающие растения. Musa basjoo Sieb. et Zucc., Aspidistraelatior Blume

Общее распространение. Тропические зоны.

C. orchidearum Allesch., Rabenhorst's KryptogamenFlora, Pilze — Fungi Imperfecti 1(7): 563 (1902)

Морфология. Конидии продолговатые, яйцевидные, иногда удлиненно-овальные, одноклеточные, бесцветные. Конидиеносцы цилиндрические, в основном короткие.

Биологические особенности микромицета и патогенез.C. orchidearum зимуют в форме мицелия в пораженных побегах. Весной образуется конидиальное спороношение и телеоморфа. Конидии в условиях закрытых грунта распространяются путем капельножидкой влаги. В местах поражения образуется мицелий. На эпидермисе пораженной ткани растений образуется ложе конидиеносцев с конидиями. Конидии прорастают при температуре от +100 д до +390С и высокой влажности.

Питающие растения. Cattleya hybrida hort., Cymbidium hybridum hort., Coelogyne cristata Ldl., Dendrobium nobile Ldl., Stanhopea tigrina Batem.

Общее распространение. Широко распространен по миру.

\section{C. roseolum Henn., Hedwigia 44: 176 (1905)}

Морфология. Мицелий расположен в межклетниках растительных тканей и образуется в вегетационный период. Конидии продолговатые, немного серповидные. На верхнем конце часто утолщены и сужены в форме клювика. Размеры: 14,1-31,6х5,2-7,9 мкм. Конидиеносцы конические, утончающиеся в верхней части. Размеры $11,8-16,7 \times 1,4-3,2$ мкм.

Биологические особенности микромицета. На инфицированных органах микромицеты развивают спо- 


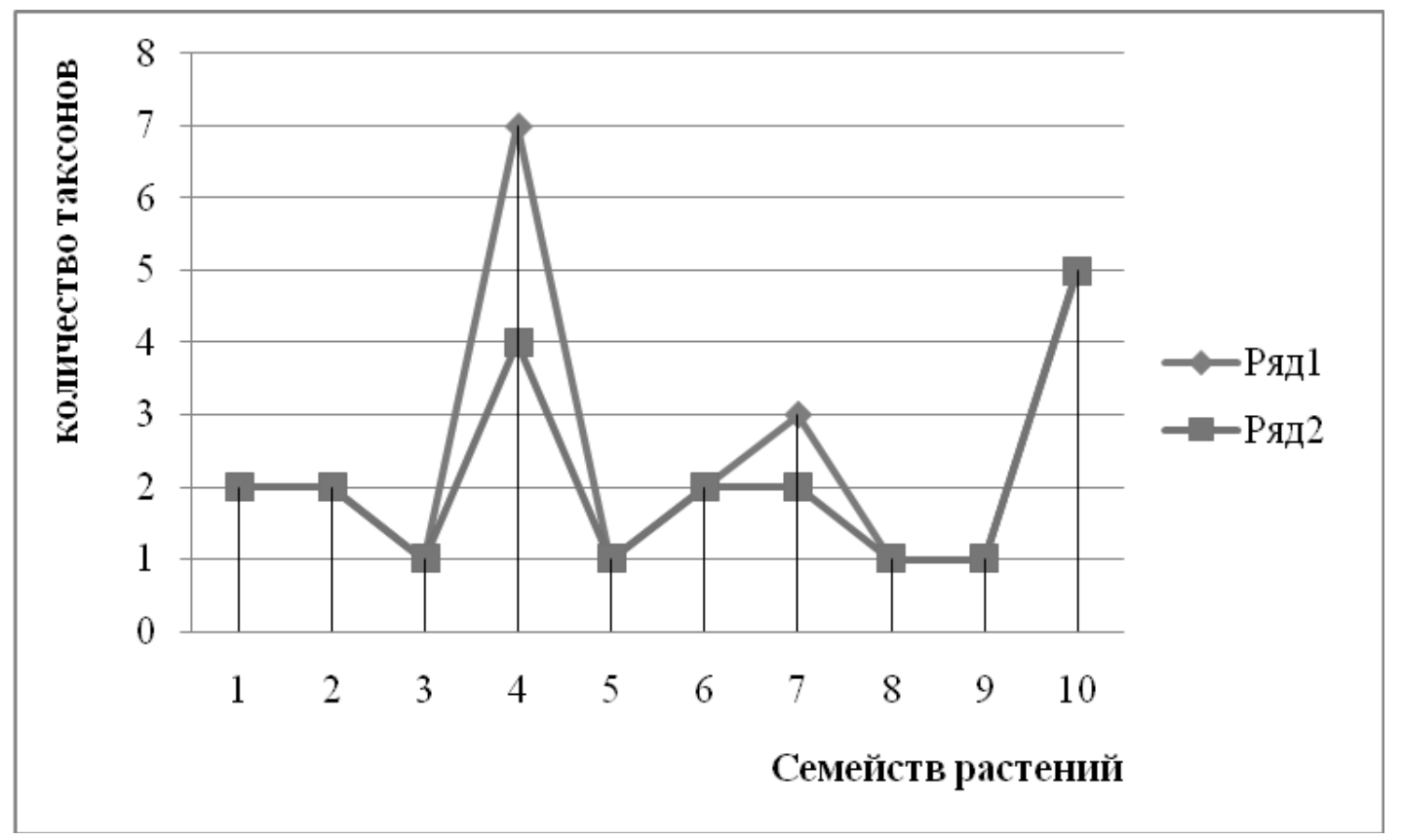

Рис. 1. Распределение таксонов коллетотрихальных микромицетов с учетом питающих тропических растений:

1. Arecaceae; 2. Amaryllidaceae; 3. Bromeliaceae; 4. Cactaceae; 5. Lauraceae;

6. Rutaceae; 7. Araceae; 8. Musaceae; 9. Liliaceae; 10. Orchidaceae.

1 - количество видов; 2 - количество родов

роношение в форме многочисленных подушечек, располагающихся концентрическими кругами или сливающимися в сплошной налет. Микромицеты развиваются при температуре от $+4,50$ д до +300 C. Оптимум от $+19,50$ C-+220С до $+25,50$ C-+290С. Оптимальная влажность 88-97\%. Особенно интенсивно микромицет развивается в теплых и влажных условиях.

Питающие растения. Cattleya hybrida hort., Cymbidium hybridum hort., Coelogyne cristata Ldl., Dendrobium nobile Ldl., Stanhopea tigrina Batem.

Общее распространение. Широко распространен в тропических зонах.

C. orthianumKostlan, Festschr. 70. Geburtstage A. Orth.: 113 (1905)

Морфология.Конидии одноклеточные, бесцветные, продолговатые, серповидно-изогнутые. Размеры: 14,30×5,1-8,3 мкм. Конидиеносцы одноклеточные, бесцветные, палочковидные, суженные в верхней части. Размеры: 11,9-17×2,7-3,2 мкм. Размер микроконидии $5,1-6,8 \times 1,4,5-2,3$ мкм.

Биологические особенности микромицета.Микромицет вызывает пятнистость листьев, представитель се- мейства Orchidaceae. Микромицет C. orthianum имеет форму подушечек, расположенных в эпидермисе, которые открываются неравномерно. Первые признаки болезни появляются в начале (первая декада) мая и до третьей декады июня.

Проявление болезни можно заметить на нижних более старых листьях, затем болезнь постепенно переходит на вновь отрастающие листья и листовые влагалища, при благоприятных условиях может распространиться на большинство листьев и вызывать их увядание.

Питающие растения. Cattleya hybrida hort., Cymbidium hybridum hort., Coelogyne cristata Ldl., Dendrobium nobile Ldl., Stanhopea tigrina Batem.

Общее распространение. Широко распространен в тропических зонах.

Возбудителями болезни антракноза в закрытом грунте Центрального ботанического сада часто поражаются растения из семейств Cactaceae (7; 28,0\% от общего числа зараженных видов растений), Orchidaceae (5; 20,0\%), Araceae(3; 12,0\%). Реже можно обнаружить виды рода Colletotrichum на растениях семейств Arecaceae, Amaryllidaceae, Rutaceae $(2 ; 8,0 \%)$, Bromeliaceae, Lauraceae, Musaceae, Liliaceae $(1 ; 4,0 \%)$ (Рис. 1). 
Таблица 2. Абсолютное и относительное количество видов растений, питающих микромицетов рода Colletotrichum

\begin{tabular}{|c|c|c|c|}
\hline \multirow{2}{*}{$\begin{array}{l}\text { Название видов патогенных микромицетов рода } \\
\text { Colletotrichum }\end{array}$} & \multirow{2}{*}{$\begin{array}{l}\text { Название родов } \\
\text { питаюших растений }\end{array}$} & \multicolumn{2}{|c|}{ Число видов питаюших растений } \\
\hline & & абсолютное, шт. & относительное,\% \\
\hline C.gloeosporioides & Opuntia & 3 & 12,0 \\
\hline C. crassipes & Rebutia & 2 & 8,0 \\
\hline C. crassipes & Parodia & 1 & 4,0 \\
\hline C.gloeosporioides & Mammillaria & 1 & 4,0 \\
\hline C.gloeosporioides, C.destructivum & Anthurium & 2 & 8,0 \\
\hline C.gloeosporioides & Zantedeschia & 1 & 4,0 \\
\hline C. crassipes & Phoenix & 1 & 4,0 \\
\hline C. crassipes & Chamaerops & 1 & 4,0 \\
\hline C. crassipes & Vallota & 1 & 4,0 \\
\hline C. cliviae & Clivia & 1 & 4,0 \\
\hline C. crassipes & Ananas & 1 & 4,0 \\
\hline C.gloeosporioides & Persea & 1 & 4,0 \\
\hline C.gloeosporioides & Citrus & 1 & 4,0 \\
\hline C.gloeosporioides & Fortunella & 1 & 4,0 \\
\hline C. musae & Musa & 1 & 4,0 \\
\hline C. musae & Aspidistra & 1 & 4,0 \\
\hline $\begin{array}{l}\text { C. orchiderum, C. roseolum, } \\
\text { C. orthianum }\end{array}$ & Cattleya & 1 & 4,0 \\
\hline $\begin{array}{l}\text { C. orchiderum, C. roseolum, } \\
\text { C. orthianum }\end{array}$ & Cymbidium & 1 & 4,0 \\
\hline $\begin{array}{l}\text { C. orchiderum, C. roseolum, } \\
\text { C. orthianum }\end{array}$ & Coelogyne & 1 & 4,0 \\
\hline $\begin{array}{l}\text { C. orchiderum, C. roseolum, } \\
\text { C. orthianum }\end{array}$ & Dendrobium & 1 & 4,0 \\
\hline $\begin{array}{l}\text { C. orchiderum, C. roseolum, } \\
\text { C. orthianum }\end{array}$ & Stanhopea & 1 & 4,0 \\
\hline Итого: 8 вид & 21 род & 25 & 100 \\
\hline
\end{tabular}

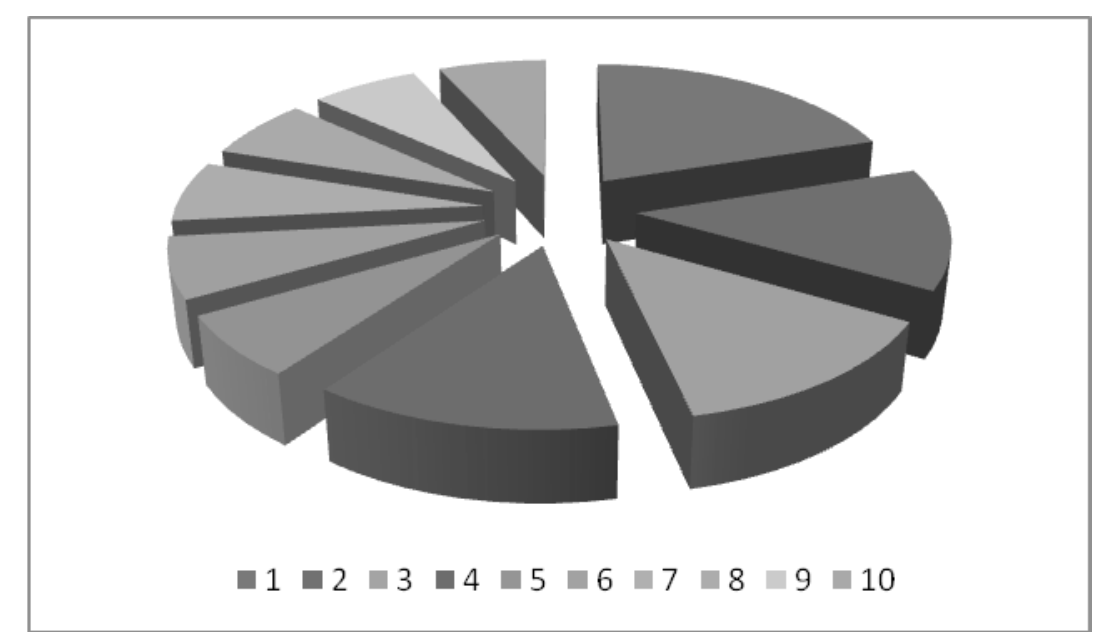

Рис. 2. Распределение таксонов коллетотрихальных микромицетов с учетом общего числа видов по семействам питающих тропических растений:

1 - Orchidaceae - 37,5\% (3 вида); 2 - Cactaceae- 25,0\% (2 вид);3 -Amaryllidaceae- 25,0\% (2 вида); 4 Araceae - 25,0\% (2 вида); 5 - Arecaceae- 12,5\% (1 вид); 6 - Rutaceae - 12,5\% (1 вид); 7 - Bromeliaceae-

12,5\% (1 вид); 8 - Lauraceae - 12,5\% (1 вид); 9 - Musaceae- 12,5\% (1 вид); 10 - Liliaceae - 12,5\%

(1 вид). 
При анализе родовой насыщенности питающих растений обнаруживается, что в большей степени антракнозу подвержены роды Opuntia(3 видов растений; 12,0\% от общего числа видов растений), Rebutia, Anthurium(2; 8,0\%). Остальные роды представлены одним видом питающих растений (4,0\%) (Таблица 2).

В результате исследования установлено, что выявленные патогенные виды коллетотрихальных грибов заразили разные виды тропических растений: Colletotrichum crassipes встречаетсянаPhoenix dactylifera,Chamaerops humilis, Vallota speciosa, Ananascomosusvariegatus, Parodia magnifica, Rebutia krainziana, R. minuschula; C.gloeosporioides - на Persea americana, Citrus limon, Fortunella margarita, Opuntialindheimeri, Op. linguiformis, Op. macracantha, Mammillariaprolifera, Anthurium andreanum, Zantedeschia aethiopica; $C$. orchiderum, C. roseolumи C. orthianum - на Cattleya hybrida, Cymbidium hybridum, Coelogyne cristata, Dendrobium nobile, Stanhopea tigrina; лишь некоторые обладают узкой специализацией растений-хозяев: Colletotrichum destructivum встречается на Anthurium scandens; C. cliviae- на Clivia miniata.

Наибольшее число патогенных микромицетов обнаружено на представителях семейства Orchidaceae (3 возбудителя антракноза; 37,5\% от общего числа видов) и семейств Cactaceae, Amaryllidaceae, Araceae (2; 25,0\%). На остальных растениях микромицеты данного рода представлены одним видом (12,5\%) (Рис. 2).

Появление этих возбудителей болезни антракноза в нашей стране (Азербайджана) связано с завозом зараженных черенков и растений из-за рубежа, где эта культура выращивается для озеленения закрытого грунта как красивое декоративное растение.

\section{ЛИТЕРАТУРА}

1. Афонин А. Н., Грин С. Л., Дзюбенко Н. И., Фролов А. Н. (ред.) Агроэкологический атлас России и сопредельных стран: экономически значимые растения, их вредители, болезни и сорные растения, 2008. http://www.agroatlas.ru

2. Гасымов Ш. Н. Коллекционный фонд тропических и субтропических растений Центрального ботанического сада. // “Интродукция и акклиматизация растений" (Труды Центрального Ботанического сада НАН Азербайджана), Баку, 2004. Том IV, c. 142-148.

3. Головкин Б. Н., Чеканова В. Н., Шахова Г. И. и др. Комнатные растения: Справочник. — М.: Лесн. пром-сть, — 1989. — 431 с.

4. Кузнецова Н. П., Падюкова А. М. Вредители тропических и субтропических растений закрытого грунта Сибирского ботанического сада // Бюл. ГБС. - 1998 . Вып. 176.-С. 165.

5. Проценко Е. П., Сёлочник Н. Н., Миско Л.А. 0 патогенной микофлоре тропических и субтропических растений Главного ботанического сада АН СсСР // Защита растений от вредителей и болезней. — М.: ГБС АН СССР, - 1974. Т. 3.— С. 93-122.

6. Черевченко Т. М., Приходько С. Н., Майко Т. К. и др. Тропические и субтропические растения закрытого гркнта: Справочник.- Киев: Наук. думка,1988. - 412 c.

7. Ampt E. A., van Ruijven J., Raaijmakers, J.M. et al. Linking ecology and plant pathology to unravel the importance of soil-borne fungal pathogens in species-rich grasslands.// Eur J Plant Pathol., 2019, 154, 141-156.

8. https://www.tandfonline.com/doi/full/10.1080/21655979.2019.1649520 САВІ Bioscience Datebase — http://www.mycobank.org (по состоянию на 10.05.2020)

9. Cannon P. F., Damm U., Johnston P. R., Weir B. S. Colletotrichum — current status and future directions. // Studies in Mycology, — 2012. 73: 181-213. https://doi. org/10.3114/sim0014

10. Chen G, Sun W. The role of botanical gardens in scientific research, conservation, and citizen science.//Plant Divers. 2018;40(4):181-188.

11. Crous P.W., Hawksworth D. L., Wingfield M. J. Identifying and naming plant-pathogenic fungi: Past, present, and future. // Annual Review of Phytopathology 2015, 53,-pp. 247-267.

12. Damm U., Barroncelli R., Cai L., Kubo Y., O'Connell R., Weir B., Yoshino K., Cannon P. F. Colletotrichum: species, ecology and interactions. // IMA Fungus — 2010. 1:161-165.

13. Everett K. R. Anthracnose and Stem-End Rots of Tropical and Subtropical Fruit-New Names for Old Foes. In: Prusky D, Gullino ML (eds.) Post-harvest Pathology, // Springer International Publishing - 2014. - pp. 55-70.

14. Guo M., Pan Y. M., Dai Y. L., Gao Z. M. First report of brown blight disease causef by Colletotrichum gloesporioides on Camellia sinensis in Anhui Province, China. // Plant Disease. — 2014. 98(2): 284-284. https://doi.org/10.1094/PDIS-08-13-0896-PDN

15. Kenny M. K., Galea V. J., Price T. V. Germination and growth of Colletotrichum acutatum and Colletotrichum gloeosporioides isolates from coffee in Papua New Guinea and their pathogenicity. // Australasian Plant Pathology — 2012 (online, doi:10.1007/s13313-012-0117-7)

16. Kirk P. M., Cannon P. F., Minter D. W. Stalpers J. A. Dictionary of the fungi, 10th edn. CABI publishing. Wallingford (UK), 2008, 600p.

17. Lazarovits G., Turnbull A., Johnston-Monje D. Plant health management: biological control of plant pathogens. In: Van Alfen NK, editor. Encyclopedia of agriculture and food systems. New York, NY: Academic Press; 2014. p. 388-399.

18. Liu F., Wang M., Damm U., Crous P.W., Cai L. Species boundaries in plant pathogenic fungi: a Colletotrichum case study. // BMC Evolutionary Biology — 2016, 16, article 81 
19. O)Connell R.J., Thon M. R., Hacquard S., Amyotte S. G., Kleemann J., Torres M. F. et al. Lifestyle transitions in plant pathogenic Colletotrichum fungi deciphered by genome and transcriptome analyses.//Nat Genet., 2012;44(9):1060-1065.

20. Savary S., Ficke A., Aubertot J. N., and Hollier C. (2012). Crop losses due to diseases and their implications for global food production losses and food security.//Food Secur. 2012, 4, 519-537.

21. Shuping D. S.S., Eloff J. N. The use of plants to protect plants and food against fungal pathogens: a review.// Afr J Tradit Complement Altern Med., 2017;14(4):120127.

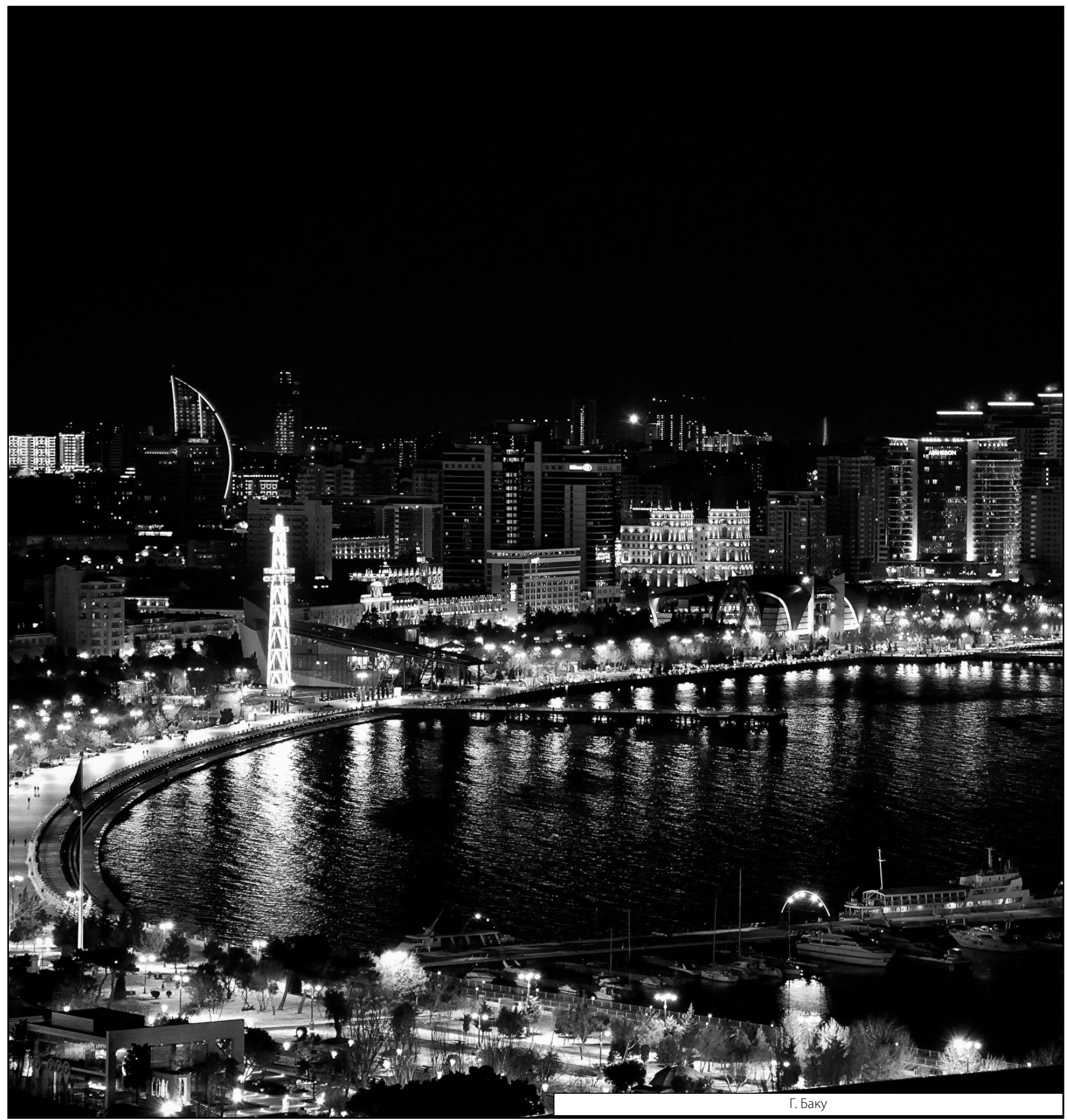

